\title{
Study on the Cultivation of College Students' Innovation Ability by Subject Competition and Its Countermeasures
}

\author{
Qi Lian \\ School of Foreign Languages and International Trade \\ Wuhan Polytechnic \\ Wuhan 430074, China \\ Lianqi027@qq.com
}

\begin{abstract}
Innovation and entrepreneurship education has become a national development strategy. College students discipline competition into an important period of development. This paper enumerates the problems existing in the discipline competition of university students and gives some measures to improve their discipline competition and the cultivation of their innovation ability.
\end{abstract}

Keywords - college students; competition; innovation; teaching philosophy; advice

\section{INTRODUCTION}

In recent years, under the background of the national development strategy "mass entrepreneurship and innovation", the whole society is holding college students' innovation and entrepreneurship competitions in full swing[1]. The Ministry of Education issued a document specifically on the innovation and entrepreneurship education for college students, requiring colleges and universities to include entrepreneurship courses in compulsory courses and make "Internet plus" an important breakthrough point in its education and teaching reform. As a result, the innovation and entrepreneurship competition for college students has entered an important period of development. This article is to talk about a few thoughts on college students' innovation and entrepreneurship competition.

\section{THE SIGNIFICANCE OF COLLEGE STUDENTS' INNOVATION COMPETITION}

"Mass entrepreneurship and innovation" is a strategy put forward by the party and the country at a new stage of historical development. Innovation and entrepreneurship education and practice in colleges and universities is an important measure to improve the core competitiveness of the country. It is of great significance to realize the strategic transformation of the Chinese economy and its sustainable development. Meanwhile, talent cultivation and teaching reform in colleges and universities also need to inject new vitality. Innovation and entrepreneurship education is also in need to promote the teaching reform in colleges and universities. The innovation and entrepreneurship competition for college students is an important part of innovation and entrepreneurship education in colleges and universities.
College students' innovation and entrepreneurship competition is essential to the cultivation of college students' innovation consciousness and entrepreneurship ability. It is the practical application of the knowledge they learned in the first class that is conducive to the combination of the knowledge they learned with social production and life and the improvement of their comprehensive ability and quality.

\section{THERE ARE MANY KINDS OF SUBJECT COMPETITIONS AND LACK OF INHERITANCE}

Innovative talents, as one of the key factors, have received great attention to revitalizing the Chinese nation. The country launched a series of policies to promote and inspire innovative talents cultivation. In November 2013, the Third Plenary Session of the 18th Central Committee of the Communist Party of China adopted the "the Central Committee of the Communist Party of China about certain major issue decision", comprehensively deepening reform and innovative entrepreneurial talent training as an important part of the strategy of reinvigorating China through human resource development. During the two sessions of the National People's Congress and the Chinese People's Political Consultative Conference, innovation has also been mentioned various times. It has become a consensus to cultivate college students' innovative thinking and independent innovation ability, and promote the national spirit with patriotism as the core and the spirit of the times with reform and innovation as the core. The cultivation of innovative thinking is also one of the key contents of the cultivation of innovation and entrepreneurship ability. However, in recent years, colleges and universities generally attach great importance to the development of students' practical ability of innovation and entrepreneurship, but there is still a lack of systematic cultivation and practice of innovative thinking.

\section{A. Teaching system that emphasizes theory over practice}

The teaching system of colleges and universities is dominated by theory teaching and supplemented by practical teaching. At the same time, relative to the theoretical teaching, practical teaching is not only a more diverse teaching form, but the requirement of teachers' practical ability and teaching level is higher and the content and practice examination methods are 
more flexible, therefore in the process of actual execution, it shows a tendency of certain theory over practice, leading to the lack of enough exercise of students' practical ability and creative thinking training. As for teachers in colleges and universities, however , the practical and innovation ability level are diversified. Some teachers, especially new employees, because of the lack of sufficient practical experience, they lay particular stress on the theory in the process of teaching, which also influences and limits the cultivation of students' practical ability and innovative thinking.

\section{B. A training method that emphasizes skills over thinking}

Under the existing teaching system, because of the less practice in part of the class, the link of knowledge is weak and teachers face some new or sudden problems during the experiment, namely for students, through the study of theory of subject teaching, their ability to carry out experiment in the lab still varies and they can't experiment task independently, and so on and so forth [3]. Some students even don't know the experiment principle, not to mention the experimental innovation. So when teachers arrange the experiment contents, they usually give priority to the classical experiment in the teaching process, although the basic practical ability of students in exercise helps. However, classic experiment aims to highlight the basic principle and key points of the experiment process and it tends to be more rigid and boring, affecting the student's study interest, hence resulting in the lack of the cultivation of students' creative thinking ability[3].

\section{An evaluation model that emphasizes achievements over processes}

The current college students' innovative ability training is mainly through curriculum teaching content reform and open experiment. College students' innovative projects and research projects, such as carrier to carry out, guide the student to obtain the innovative achievements through technological innovation in the process of innovation ability training, but in the process, cultivation of innovative thinking ability isn't systematic. The effective theory and practical experience and evaluation of innovation ability training also give priority to quality and quantity of technological achievements, which has not fully considered in the process of technological innovation to the students' development of innovative consciousness, innovative thinking, etc. Discipline competition, as a kind of important innovative talents cultivation and the selection of the method, is in the form of competition that stimulates the student to master the theoretical knowledge in depth, cultivates students' interest in learning and the ability of autonomous learning through the process of finding and solving practical problems, enhances college students' innovation consciousness and improves their innovative ability. Ministry of Education on higher school undergraduate teaching quality and teaching reform project of opinion holds that "continue to carry out college students' competition, focus on funding across the country that is influential, promote broad participation of college students competition and stimulate students' interests and potential, hence cultivating college students' team cooperation consciousness and innovation spirit", which will discipline competition as the reform and innovation direction of practical teaching and personnel training mode.

\section{The audience is not universal}

When some college teachers know that there is a discipline related competition, they will generally select some relatively excellent students for notification, and explain the process of competition and so on. Although today's society looks at strength, the school carries on the place of education and should not carry on the different treatment to the student or it will bring different results. It is true that students with excellent performance and ability are more likely to be selected in the discipline competition, so as to exercise themselves in the competition, but other students also need to exercise themselves in the process. This also raises new questions about how teachers can recommend different subject competitions based on the level of students. For some students with middle and lower ability, the competition of the top in the industry may really unpractical. In fact, such competition can only improve this part of students, which is very limited. In this way, teachers are required to measure the abilities of different students and recommend suitable competitions to them. Through this way, students can exercise and learn in competitions that are suitable for their abilities and make progress gradually. Eventually, they will be able to have access to the competitions of authority in the discipline.

\section{SUGGESTIONS ON THE CURRENT INNOVATION COMPETITION FOR COLLEGE STUDENTS}

\section{A. Cultivation of innovation consciousness}

Cross major independent team is a good way to solve the college students' participating problem of complementary skills and team cooperation, and for the cultivation of college students' innovative thinking, it has laid a good foundation. However, innovative thinking and technology innovation ability of college students is poor, therefore, in terms of innovative thinking and technology innovation ability, it stillneeds guidance system of training and timely guidance of teacher. Good innovation consciousness is the driving force of technological innovation, the source of stimulating continuous innovation, and the key index to evaluate the success of cultivating innovative thinking of college students. The cultivation of innovation consciousness should not rely on the missionary training. Instead, it should make students realize that only by innovation can they win the competition through detailed analysis and scientific summary of the winning teams in previous competitions. At the same time, it is necessary for students to analyze that technological innovation not only brings good competition results, but also forms technical achievements such as papers, patents and software copyrights through further arrangement, and amplifies the benefits of competition results. Only by making students truly realize the potential benefits brought by innovation can students' innovation awareness be improved. Tianchi big data competitions, for example, at the beginning of the game, by organizing students to deeply analyze the previous tianchi big data competition award scheme in the calendar year, especially the creative thinking of the winning team in the past, innovations, and innovation achievements, etc. It will help students to set up the "only innovation can win" concept, strengthening the students' innovation consciousness. 


\section{B. Cultivation of innovation ability}

Creative thinking is the organic complementarity of logical and non-logical thinking, divergent and concentrated thinking, combined and decomposition thinking, homologous and divergent thinking, subconscious and conscious, which play a very important role in creative activities[4]. The cultivation of innovation ability, on the one hand, needs to cultivate the innovation consciousness of college students, stimulate students' innovation behavior; on the other hand, it also needs to guide students to form a good innovative thinking scientifically and improve innovation ability. In the aspect of training innovative thinking for students in the library, it can carry on innovative thinking training on a regular basis, improve students' understanding of the technical innovation patterns and rules At the same time, it can encourage students to emancipate the mind, break the professional and the limits of thinking, give full play to the subjective initiative, realize the integration of different professional knowledge application through brainstorming cross major students, and solve the actual problems in the competition of big data with innovative technology and method. For 2017 computer learn big data and computing intelligence contest game, for example, in the middle of the competition, the performance of the prediction model for student team encounters the bottleneck, then teachers team from the innovative thinking of the complementarity of the common thinking and questioning mind guide students on the direction of innovation: in seeking common thinking ways, students are required to pay attention to details, investigating the existing of the latest technology and popular solutions, comparison and analysis the winning design, before the game is likely to do a good job of data exploration and analysis of data base, work well with another team similar basis. At the same time, the analysis of the whole process of data processing, on the basis of encouraging students from data processing framework, method of data preprocessing, feature engineering, feature selection, data processing algorithm, data fusion model and predict the results of robust estimation methods, seeks differences with other team with innovative technology and method and improves the data analysis process or some specific link to better improve the forecasting performance of the model.

\section{Cultivation of innovative achievements}

Undergraduate course contests require to guide students to better right subject contest in the process of the result of the technical and method innovation, further formation of papers, patents and software copyright, such as academic achievements On the one hand, It can better promote the benefits of big data race and encourage students' enthusiasm to take part in the game; on the other hand, by forming the academic achievements of innovation, it can better able to form a virtuous cycle and strengthen students' innovation consciousness. The cultivation of innovative achievements should be planned from the beginning of the competition, and the cultivation of innovative achievements should be regarded as one of the objectives of the competition, so as to establish students' innovative consciousness. In the game, to encourage students is not only for competitions and participation in the competition, but by taking part in competition of big data, with the help of analysis of the actual data and communication with other players to improve their practical and innovation ability. We should pay attention to the process of the game through the scientific research to master the latest technology and methods, and combine with the problem of practical problems to put forward innovative technology and method, thus to gain competition awards in the formation of academic research results at the same time[2]. Innovation cultivation is for a lot of students and discipline competition is easily to ignore the link, in part because many students team do participate in the process of the limited original work, which is difficult to form good results; another reason is that usually the innovation results also need further study, even need more time than entry process. In students' cultivation, teachers should attach importance to the innovation achievements, to timely understand the student's innovative ideas, encourage students around course contests to do some creative work, and according to the innovative work, students are encouraged to form a patent for invention, Chinese core paper, EI conference papers or SCI journal articles, etc., so as to realize the innovation ability cultivation, academic research and big data organic integration of the game, at the same time teachers also can greatly inspire the enthusiasm of the students when engaging in a subject to improve the students' innovation consciousness and innovation ability[5].

\section{Professional competence development}

Professional competence is the most basic skill that students need to master in the professional field. The good or bad professional competence proves one's learning attitude to some extent. The national 985 and 211 and the current "double first-class" construction projects all focus on talent training. Compared with ordinary universities, the faculty of "double first-class" universities will be more excellent, and their students will learn more excellent professional skills from their teachers. However, in the past, the education policy of colleges and universities mainly focused on the professional skills of students and limited the courses of colleges and universities to books and classrooms. Such education policy indeed ensured the basic professional standards of students. However, with the progress of the society and the development of science and technology, students who only pay attention to professional ability will find it extremely difficult to progress in their work if they only have solid professional ability while lacking other comprehensive qualities after entering the society. Deep professional ability can ensure students' knowledge and skills, but only professional ability also limits students' development.

\section{MEASURES TO PROMOTE THE EDUCATION POLICY OF UNIVERSITY COMPETITION}

\section{A. Set up the teaching idea with innovation as the core}

Advanced teaching concept needs to overcome the disadvantages of the universal content and single method. To explore a broader vision, we should not be limited to books, but from the knowledge, quality, ability, practice and other aspects of teaching. Most of the knowledge is acquired from professional courses and books, while the quality and ability are acquired by actively practicing outside the books. Therefore, to set up the teaching concept with innovation as the core will 
enable students to subjectively explore innovation, combine theory with practice, and combine knowledge with innovation. In this way, students will be interested in competition based on learning professional courses, and then participate in and harvest. It mainly includes the following points:

Adjust teaching assessment standards. The grading standards given in vocational skill competition have strong reference significance for the evaluation system of practical training courses in higher vocational colleges. Practical teaching is the most important link in the process of higher vocational teaching, which is related to the quality of students' training and their employability. Therefore, vocational education should strengthen practical teaching and emphasize the cultivation of students' practical ability. In recent years, the content of vocational skills competition is no longer limited to books, but to enterprises. The content and standards of competition are jointly formulated by schools and enterprises. Practical teaching in higher vocational colleges can be assessed through the process and result of skill competition, and the quality of practical teaching can be quantitatively assessed by the scoring standard of skill competition.

We will strengthen the building of an innovation team. Through discipline competition, colleges and universities can strive to build an innovative team led by teachers and dominated by students, attract more students to join in through various ways, fully mobilize students' enthusiasm, and implement universality and emphasis at the same time. Universality means that every student can participate in the discipline competition through the teacher's guidance and students' cooperation in the team, so as to achieve the mass nature of scientific and technological innovation. After all, not all students are at the same level. Schools and teachers should also find a group of outstanding talents in the large group of students and let them fully play a leading role in the participation of some discipline competitions at the national level and abroad. Schools should involve as many students as possible in order to cultivate more innovative and interdisciplinary talents[6]. While paying attention to the students, the faculty also cannot be ignored. A teacher's guidance affects the final quality and style of the entries to some extent. Therefore, only by building a high-level team of teachers and students can we promote the development of competition education policy.

Establish sound incentive policies. The advice of colleges and universities perfect the encouragement policy, course contests and other activities with credits and comprehensive quality assessment and awards recommendation. We know that learn to study and all aspects of the college students' education is closely related to the combination of fully stimulating students' initiative and enthusiasm, thus promoting role in the quality of entries, and make students who won prizes feel recognized from the incentives and for those who get no prize, teachers can award students and then they will try harder. In this way, more and more students will continue to participate in the education policy competition.

\section{CONCLUSION}

In the 21st century today, the arrival of the economic age and the information age put forward a very severe test of innovation for college students. The cultivation of innovation ability has also triggered more and more people's thinking, and the competition education policy can be regarded as a very effective policy to cultivate college students' innovation ability. Although the currently active mode, some problems still exist, but we believe that after continuous effort, race education mode can let more and more college students to grow, gain acquisition of innovation ability in the competition and cooperation ability, realize the great rejuvenation in the new century for contemporary college students through the experience of the competition in this era of high quality requirements.

\section{REFERENCES}

[1] LI wei, LI zhu. Thinking Characteristics, Formation Mechanism and Training Path of Innovative Talents in Colleges and Universities [J]. Jiangsu Higher Education, 2017(11): 77-80.

[2] LIU Xingqiang, WANG Lin. Research on Cultivation of College Students' Innovative Thinking [J]. Innovation and Entrepreneurship Education, 2017(3): 24-26.

[3] ZHANG Lili, YANG Wengu, LI Dayu, et al. Exploration of Cultivating Students' Innovative Thinking Mode Based on Open Experiment [J]. Experimental Technology and Management, 2016(07): 29-32.

[4] FAN Zhong-cheng, XUE Man-ling. Cultivating Innovative Thinking of Computer Major Undergraduates in Classroom Teaching [J]. Journal of Higher Education, 2015(24): 89-90.

[5] LU Meng-li, NIE Xiao-jun, SONG Wei-ning. A Brief Analysis of the Role of College Students' Innovative Projects in Cultivating Innovative Thinking [J]. China Forestry Education, 2016(3): 7-9.

[6] YANG Jian-liang. Practical Research on the Effective Integration of Skills Competition and Professional Teaching [J]. China Vocational and Technical Education,2013(2):19-24. 